\title{
Gonadal state and condition factor of Oreochromis niloticus (Linnaeus 1758)in a hypereutrophic lake
}

\author{
Beaven Utete", Edmore Happison Chikova \\ Chinhoyi University of Technology, Department of Wildlife and Safari Management P. Bag 7724, Chinhoyi
}

Email address:

beavenu@yahoo.co.uk(B. Utete), butete@cut.ac.zw(B. Utete), mkaiyo@gmail.com (B. Utete)

\section{To cite this article:}

Beaven Utete, Edmore Happison Chikova. Gonadal State and Condition Factor of Oreochromis Niloticus (Linnaeus 1758)in a Hypereutrophic Lake.Journal of Water Resources and Ocean Science. Vol. 2, No. 6, 2013, pp. 165-169.

doi: 10.11648/j.wros.20130206.12

\begin{abstract}
Condition factor, sexual maturity and length-weight relationship of 1132 Oreochromis niloticusinhabiting the hypereutrophic Lake Chivero in Zimbabwe were studied. Fish samples were collected through gill netting and from selected commercialfisheries around the lake from February - November 2011. Comparative analysis of age and size at maturity revealed that the $O$. niloticus reached maturity at $30 \pm 2.5 \mathrm{~mm}$ males and $50 \pm 3.6 \mathrm{~mm}$ females in total length. There was a significant difference in sexual maturity in both sexes with the inactive (I) stage more frequent. Both sexes of fish indicated a negative allometric increase in weight.August and November were determined as the most intensive and sensitive breeding periods for $O$. niloticus in Lake Chivero.Fishing activities in the lake need to be regulated in tandem with the breeding cycles of the $O$. niloticus.
\end{abstract}

Keywords: Allometric Growth,Maturity Stage, Oreochromis Niloticus, Pollution

\section{Introduction}

Fish is an important resource in the economic development of many societies. Besides being a cheap source of readily available protein, it contains more essential nutrients required by the body [1]. It is important to monitor the growth and development of fish to optimise yields [2]. In tilapia farming (both wild and domestic) length and weight measurements in tandem with gonadal maturity and age data are vital sources of information on their lifespan, age at maturity, mortality and development $[3 ; 4]$.

Fish condition factor $(\mathrm{K})$ is based on the hypothesis that heavier fish of a particular length are in a better physiological condition [5].And the fact that fish condition factor is strongly influenced by both biotic and abiotic environmental conditions mean it can serve as a proxy to assess the status of the aquatic ecosystem in which the fish live and for further purposes of new stocking [6].In this short communication we assess the fish condition factor $(\mathrm{K})$ and evaluate the sexual maturity of the Oreochromis niloticus in a hypereutrophic subtropical lake (Lake Chivero) in Zimbabwe. Primarily this research was prompted by the fact thatOreochromis niloticusforms the backbone of commercial fisheries in Lake Chivero which is highly productive all year round such that there is commercial fishing and angling for it all year round. This is despite the fact there are some sensitive stages where gonadal development and breeding is intensive in $O$. niloticus which might need a reduction in the fishing effort [7].

\section{Materials and Methods}

The study was conducted in Lake Chivero, Harare, Zimbabwe at an altitude of 1368.59 metres above sea level and extending from 17'59' south to30'59' east.The lake was built by the impoundment of Hunyani River in 1952 and has two inflowing rivers Mukuvisi and Marimba for the purpose of supplying water to the city of Salisbury (Harare) [8]. These small rivers provide the lake with approximately 160000 cubic metres of treated and untreated sewage effluent almost daily and this effluent is the main cause of eutrophication in the lake [9]. Gill net sampling was done from February -November 2011 in the lake at sites used by commercial fisheries. Some fish samples were obtained from commercial fisheries. A total fish population of 1132 (659 males and 473 females) were collected and assessed for total length (TL) and standard length (SL) to the nearest $\mathrm{mm}$, and weight to the nearest $0.5 \mathrm{~g}$. Fish were dissected to 
determine sex and gonadal maturity stages following procedures by[10]. The maturity stages were categorized as: $\mathrm{I}=$ Inactive; $\mathrm{IA}=$ Inactive-Active; $\mathrm{A}=$ Active; $\mathrm{R}=$ Ripe; $\mathrm{RR}=$ Ripe - Ready; $\mathrm{S}=$ Spent.

Temperature of the water was measured in situ using Eutech (Model CT10-1) electronic meter at each sampling site where fish were caught. Water temperature was measured as it has been shown in other studies to affect gonadal maturation [11].

\subsection{Data Analysis}

The fisheries data obtained were sorted and analyzed using SysStat 12 for Windows version 12.02.00 [12]. Age and maturity at reproductive age was correlated to the fish condition and temperature using the Pearson correlation test (significance $\mathrm{p}<0.05$ ). ANOVA was used to assess the difference in male and female tilapia condition factor and the gonadal states. $T$ test was used to test for differences in standard and total lengths between male and female fish.Fish condition factor was calculated using the formulae:

Fish condition factor $=K=\frac{W \times 100}{S L^{3}}$

Where $\mathrm{K}=$ condition factor, $W=$ weight of fish $(\mathrm{g})$, and $\mathrm{SL}=$ standard length $(\mathrm{cm})[13]$.

The length - weight relationships were estimated from the allometric formula:

$\mathrm{W}=\mathrm{aL}^{\mathrm{b}}$

And this expression can be transformed logarithmically; $\log \mathrm{W}=\log \mathrm{a}+\mathrm{b} \log \mathrm{L}$.

Where: $\mathrm{W}=$ weight, $\mathrm{L}=$ standard length, $\mathrm{a}=$ constant and $\mathrm{b}=$ exponent of the arithmetic form of the weight -length relationship and the slope of the regression line in the logarithmic form.

When $b=3$ the fish grows isometrically, If $b>3$, the fish shows positive allometric growth and If $b<3$, then the fish shows negative allometric growth.

\section{Results}

\subsection{Fish Condition Factor and Length Weight - Relationships}

Fish condition factor was not significantly different (ANOVA; $\mathrm{p}>0.05 ; \mathrm{F}=0.6626$ ) between and within the sexes in Lake Chivero. The only months where the condition factor was significantly different (ANOVA; $\mathrm{p}<$ 0.05; $\mathrm{F}=0.4532$ )was in August and September (Figure 1). There was no significant correlation (Pearson test; $p>0.05$ ) between condition factor and gonadal maturity in both sexes of tilapia fish sampled in Lake Chivero. However, a strong relationship $(\mathrm{r}=0.78)$ existed between temperature and the inactive (I) stage of female fish. There was no significant correlation (Pearson test; $p>0.05$ ) between temperature and the gonadal stages in both sexes during the entire sampling period.

Table 1.Relative percentage (\%) abundance of different sexual maturity stages in male tilapia fish in Lake Chivero.

\begin{tabular}{lcccccc}
\hline Month & Inactive & Inactive- Active & Active & Ripe & Ripe-Ready & SPENT \\
\hline February & 0.56 & 0.33 & 0.12 & - & - & - \\
March & 0.8 & 0.16 & 0.04 & - & - & - \\
April & 0.81 & 0.16 & 0.03 & - & - & - \\
May & 0.58 & 0.31 & 0.12 & - & - & - \\
June & 0.77 & 0.17 & 0.07 & - & - & - \\
July & 0.63 & 0.16 & 0.21 & - & - & - \\
August & 0.71 & 0.29 & 0.09 & 0.01 & - & - \\
September & 0.82 & 0.08 & - & 0.02 & - & - \\
October & 0.84 & 0.13 & 0.15 & 0.02 & - & - \\
November & 0.64 & 0.19 & 0.08 & 0.01 & - & -001 \\
Overall & 0.72 & 0.19 & & & - & - \\
\hline
\end{tabular}

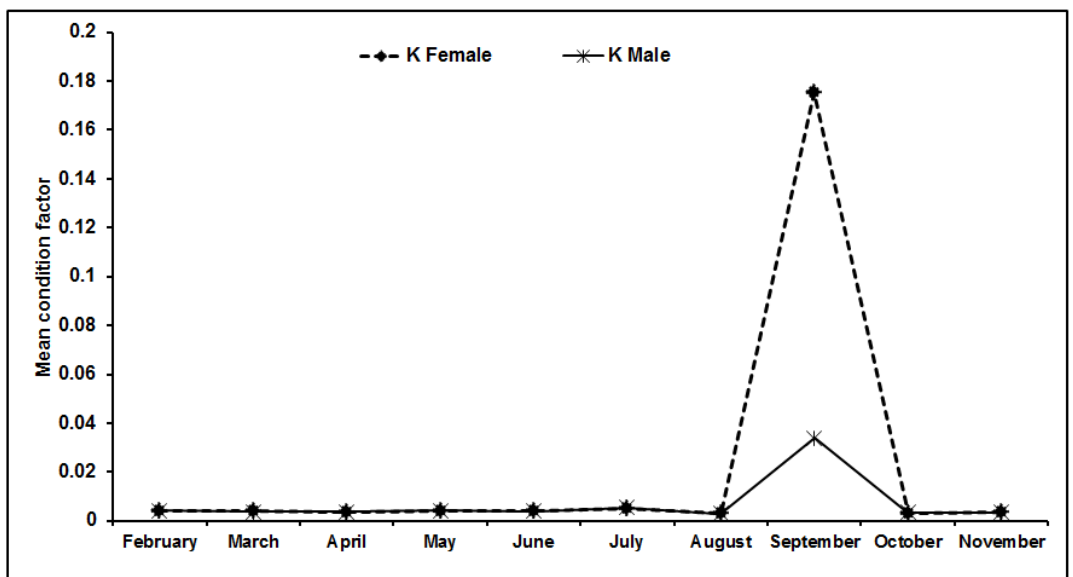

Figure 1.Condition factor of male and female O. niloticus in Lake Chivero for the period February-November 2011. 
Standard lengths of fish ranged from 30 to $226 \mathrm{~mm}$ (males), 30 to $225 \mathrm{~mm}$ (females) and total mean length between males and females did not differ significantly (student's $t=1.64, \mathrm{p}>0.05$ ). The total weight-standard length relationship was separately evaluated for all individuals. The BW-SL regressions did not differ

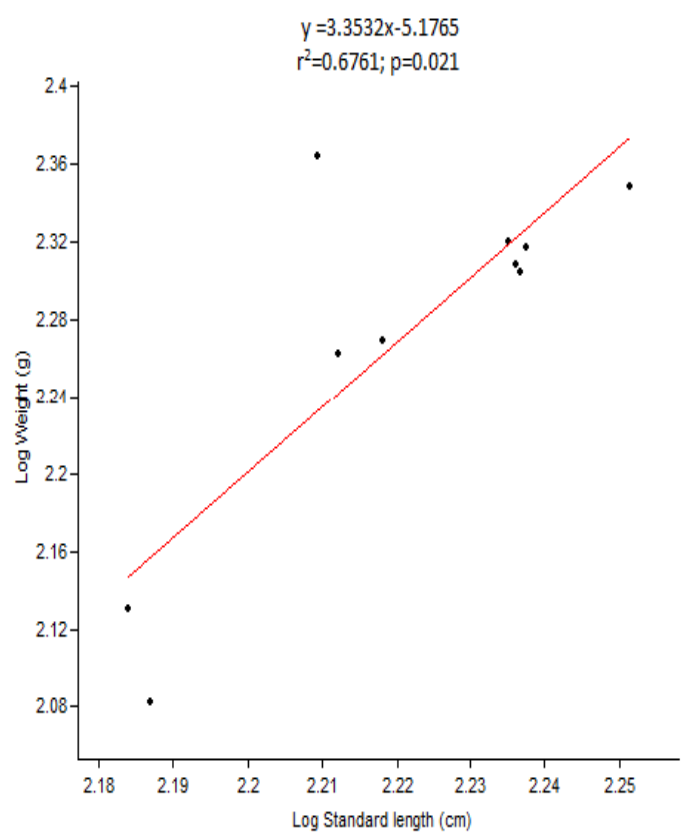

significantly between sexes (student's $\mathrm{t}=-0,077, \mathrm{p}>0.05$ ). For both sexes of tilapia sampled in this study weight increased allometrically with size (males: student $\mathrm{s} t=5.84$, $\mathrm{p}<0.05$ and females: student's $\mathrm{t}=4.76, \mathrm{p}<0.05)$. The slope values $(b)$ observed for males and females $(b<3)$ indicated a negative allometric growth (Figures $2 \mathrm{a} \& \mathrm{~b}$ ).

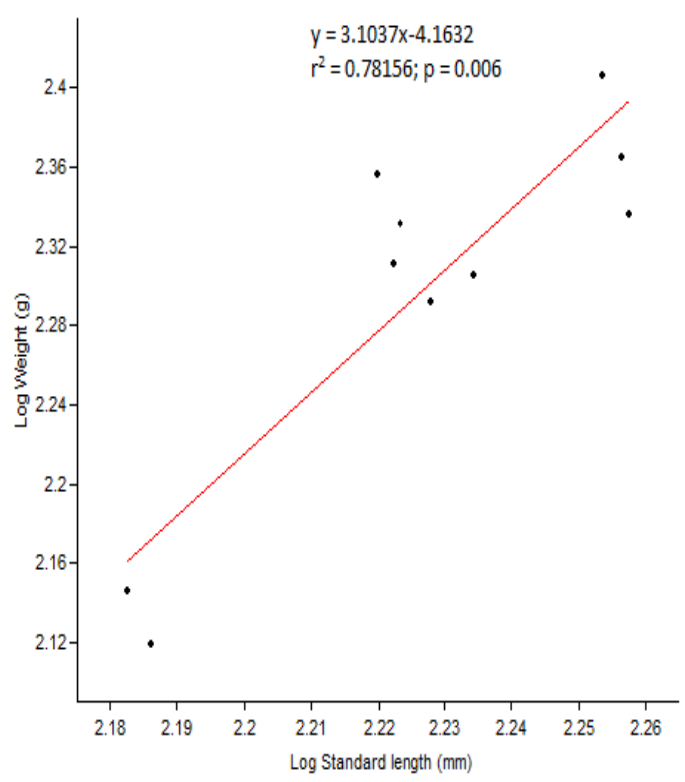

Figure $2 \boldsymbol{a} \& \boldsymbol{b}$.Length -Weight relationships in (a) male and (b) female Oreochromis niloticus fish sampled in Lake Chivero for the period FebruaryNovember (2011).

\subsection{Gonadal Development andSexual Maturity inO.Niloticus in Lake Chivero}

There were more males at gonadal maturation stages throughout the year than females. High percentages of mature active, ripe males were found in the months of April (78.8\%) and September (81.3\%) (Table1).Similarly females had a high percentage of mature active ripe stage between the months of February and September. Gonadal development in the female O.niloticus fish indicates dominating "inactive" (I) gonadal stage percentages in February, April, May, June, July and November (Table 2).
Inactive to active gonadal states were significantly high (ANOVA, $p<0.05$ ) in March, August and September in the females. Active (A) percentages were also significantly high $(\mathrm{p}<0.05)$ in October in the females. Inactive to active" (IA) ovaries were lower in February, 5.7\%, and high from April to July, 29\%. Active (A) figures were very low (10\%). Ripe individuals were caught only in March and November recording $4.2 \%$ and $3.4 \%$ respectively. Ripe and running maturity stages in female fish were recorded in July $(8.3 \%)$, September $(2.6 \%)$, and October $(4.9 \%)$ respectively (Table 2).

Table 2.Relative percentage (\%) abundance of different sexual maturity stages in female tilapia fish in Lake Chivero.

\begin{tabular}{|c|c|c|c|c|c|c|}
\hline Month & Inactive & Inactive - Active & Active & Ripe & Ripe-Ready & SPENT \\
\hline February & 0.78 & 0.11 & 0.11 & - & - & - \\
\hline March & 0.35 & 0.48 & 0.13 & 0.04 & - & - \\
\hline April & 0.56 & 0.29 & 0.15 & - & - & - \\
\hline May & 0.72 & 0.11 & 0.17 & - & - & - \\
\hline June & 0.67 & 0.29 & 0.05 & - & - & - \\
\hline July & 0.48 & 0.30 & 0.13 & - & 0.09 & - \\
\hline August & 0.51 & 0.49 & - & - & - & - \\
\hline September & 0.62 & 0.08 & 0.25 & - & 0.05 & - \\
\hline October & 0.26 & 0.23 & 0.24 & 0.23 & 0.05 & - \\
\hline November & 0.68 & 0.21 & 0.08 & 0.03 & - & - \\
\hline Overall & 0.53 & 0.25 & 0.14 & 0.05 & 0.02 & - \\
\hline
\end{tabular}




\subsection{Physical Parameter - Temperature}

Water temperature was high in March and lowered in May and June. Constant temperatures were recorded in the summer stratification period of August -November (Figure
3). There was a significant difference (ANOVA; $\mathrm{P}<0.05$ ) in surface water temperature in Lake Chivero over the months of sampling.

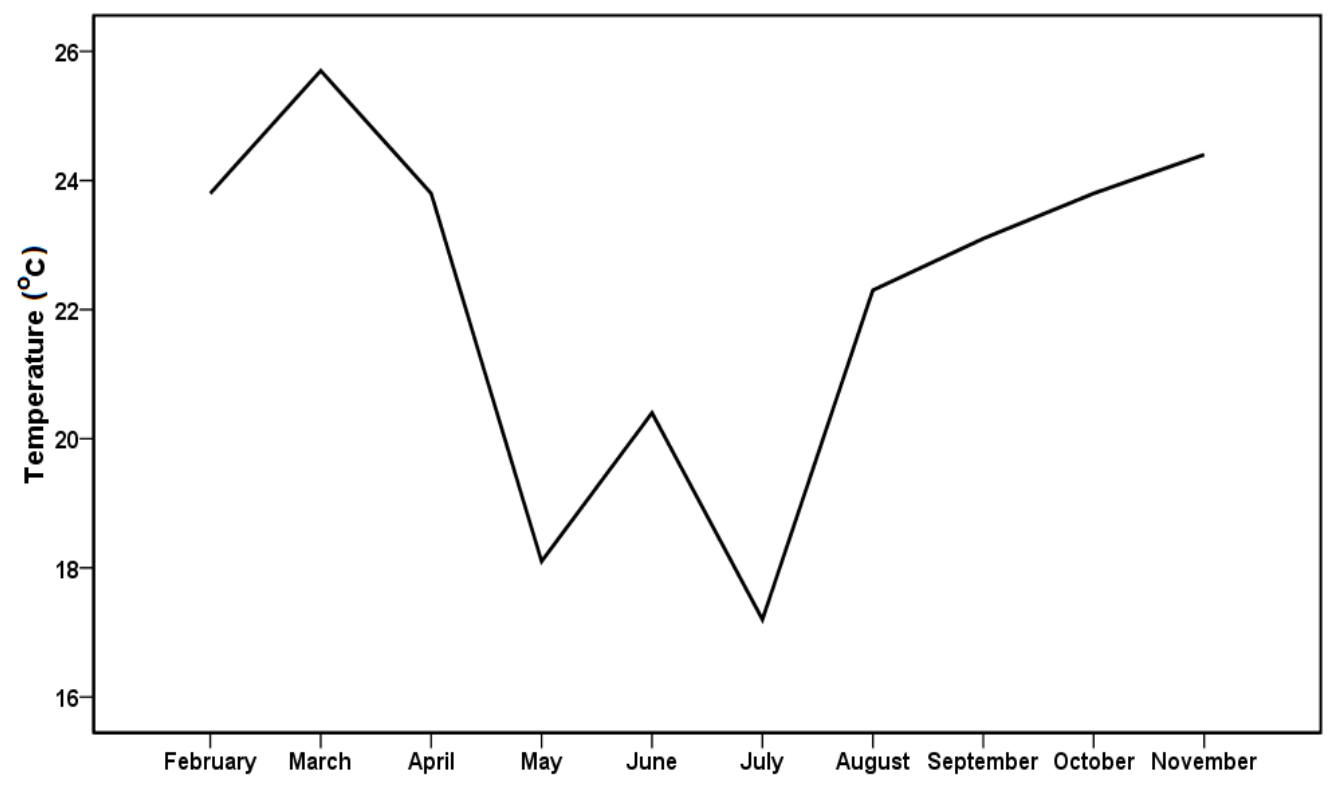

Figure 3. Water temperature of Lake Chivero for the period Feb-November 2011.

\section{Discussion}

Fish condition factor values shows an increase in the months of August, September and October, this attribute may be caused by the sexual maturation and spawning activities of larger fish in relation to improved feeding condition during the rainy season where phytoplankton production is high [14]. Nutrient inflow into Lake Chivero also increases with the onset of the rain season due to the increased surface run off in the catchment [15]. Moreover, large fish tend to have an improved condition factor; this was also discovered by [16] in Lake Timsah, Egypt, where larger fish had higher condition factor values as compared to small ones. Studies elsewhere [17;7] reveal that the weight -length relationship and fish condition factor depends on the fish species, the abiotic environment and fishing intensity in the water body.

For this study $O$. niloticus had a negative allometric growth which according to [6] implies that either large fish have changed their body shape to become more elongated or small fish were in better nutritional condition at the time of sampling. This good nutritional status can be correlated to the perennial presence of the phytoplankton as a result of pollution in Lake Chivero [14]. Studies elsewhere [18] show that length - weight relationship parameters of fish species depends on a series of factors such as season, gonad maturity, diet, health and environmental parameters. In this study the effect of an ever constant source of food seems to be significant in maintaining the good condition factor of the $O$ niloticus. Most of the fish examined exhibited lower metabolism and gonad activity during the cool-dry season, which could have contributed to the decline in fish condition factor in June-August. Fish condition sometimes reflects food availability and growth within the weeks prior to sampling, but it is variable and dynamic. Individual fish within the same sample vary considerably, and the average condition of each population varies seasonally and yearly[19]. However, our study shows that there was no significant difference in the condition factor between sexes. This may be due to the excess food that exists in the lake as pollution of Lake Chivero is not seasonal [20; 15].

Results show that there were more males at gonadal maturation stages throughout the year than females. High percentages of mature active, ripe males were found in the months of April (78.8\%) and September (81.3\%). Similarly females had a high percentage of mature active ripe stage between the months of February and September. It appears the $O$. niloticus in Lake Chivero had a high breeding intensity between the months of April -September. What this implies is that fishing activities need to be minimal in this period. Winter fish kills in Lake Chivero occur from end of April and up to the end of July [8]. This means that there is a twofold pressure on the tilapia: one of reproduction and the other one a physiological constraint placed on the metabolism of the fish due to lowered oxygen levels and elevated ammonia concentration at lake turnover. As the temperature begins to increase from Augustoxygen levels decrease in the lake which also affects maturation and metabolism [21].

Sex and gonadal development are important variables in 
some species, especially cichlids. The sex ratio of O.niloticus in Lake Chivero indicates an imbalance among males and females. For the total fish of 1132 caught 659 were males $(58.2 \%)$ and $473(41.8 \%)$ were females. Other studies have found that males tend to dominate in the cichlids population due to a number of reasons which include ability to survive postnatal mortality [21] and a better growth rate [22].Of note is that O.niloticus species in Lake Chivero breeds throughout the year but the breeding intensity was not equally distributed throughout the year. As such the lakemanagement should consider these breeding fluctuations possibly by establishing non-fishing zones during the most sensitive stages. Although pollution is detrimental in most aquatic systems, in Lake Chivero it appears that the fish condition factor is not significantly different in $O$. niloticus throughout the year possibly due to an incessant supply of nutrients.

\section{Acknowledgements}

The help of staff at the Lake Chivero Fisheries Research Station with field equipment and manpower is hereby appreciated as well as the guidance by Michael Tiki and Newman Songore in collecting the fishery data.

\section{References}

[1] Sikoki, F.D and A.J.T. Otobotekere.1999. The Land People of Bayesa State Central Niger Delta.

[2] Haimovici, M. and Velasco, G. 2000. Length- weight relationship of marine fishes from .Southern Brazil. .The ICLARM Quarterly 23(1):14-16.

[3] Diaz, L. S, Roa, A, Garcia, C. B, Acero, A, and Navas, G. 2000. Length -weight relationships of demersal fishes from the upper continental slopes of Colombia. The ICLARM Quarterly 23(3):23-25.

[4] Fafioye, O.O, and Oluajo, O. A. 2005. Length -weight relationships of five fish species in Epe .lagoon, .Nigeria. African Journal Biotechnology 4(7):749-751.

[5] Kumolu-Johnson, C.A. and Ndimele, P.E. 2010. Lengthweight relationships and condition factors of twenty-one fish species in Ologe Lagoon, Lagos, Nigeria.Asian Journal of Agricultural Science, 2: 174-179.

[6] Shakir, H.A., Mirza, M.R., Khan, A.M. and Abid, M. 2008. Weightlength and condition factor relationship of Sperata Sarwari (Singhari), from Mangla Lake, Pakistan. Journal of Animal and Plant Science 18:158-161.

[7] Hirpo, L. A. 2012. Breeding Season and Condition Factor of Oreochromis niloticus (Pisces: .Cichlidae) in Leke Babagaya. International Journal of Agricultural Sciences, 2(3):116-.120.

[8] Marshall, B. 2011 .Fishes of Zimbabwe and their biology .Smithiana Monograph 3. The South .African Institute for Aquatic Biodiversity Grahamstown.

[9] Moyo, N. A. G. 1997. Causes of Massive Fish Deaths in
Lake Chivero. In N.A.G. Moyo (Ed.), Lake Chivero: A Polluted Lake. University of Zimbabwe Publications, Harare: 98-105.

[10] Holden, M. J and Raitt, D. F.S.1974. Manual of fisheries science.2. Methods of resource investigation and their application. FAO Fisheries Technical Paper, 115, Rev, $1: 211 \mathrm{pp}$.

[11] Kotos, A. A. 1998. Food, size, and Condition factor of Oreochromis Niloticus in Niger River.Nigeria. Boil. Trop 44 (3):566-658.

[12] Systat 2007. Mystat: A student version of Systat 32-bit UNICODE English. Version 12.02.00.

[13] Bagenal, T. B and Tesch, W. F. 1978. Age and growth in methods of assessment of fish .production in freshwaters. Ed Bagenal. T. Oxford Blackwell Scientific Publication pp .101-136.

[14] Tendaupenyu, P. 2012.Nutrient limitation of phytoplankton in five impoundmentson the Manyame .River, Zimbabwe.Water SA Vol 38 (1).

[15] Mtetwa, S. 1997.Effluent and Waste Water Standards in Zimbabwe. In N. A. G. Moyo (Ed.), Lake Chivero: A Polluted Lake. University of Zimbabwe Publications, Harare: 124-134.

[16] Mahomoud, W. F., Amin, A. M.M., Elboray, K. F., Ramadhan, A. M., and El-Halfwy, M. M. M.K. O. 20Reproductive biology and some observation on the age, growth and management of Tilapia zilli.(Gerv, 1848), from Lake Timsah, Egypt.International Journal.3: 15-25.

[17] Cherif, M. Zarrad, R. Gharbi, R and Hechmi J. 2008. Length -weight relationship for 11 fish species from the Gulf of Tunis. Pan American Journal of Aquatic Sciences, 4: 67-72.

[18] Froese, R. 2006. Cube law, condition factor and weight length relationships: history, metaanalysis and recommendations. Journal of Marine Fisheries 23: 45-52.

[19] Ayoade, A.A and Ikulala, A.A.O.O. 2007. Length weight relationship, condition facto and stomach contents of Hemichromis bimaculatus, Sarotherodonmelanotheron and Chromidotilapia.guentheri (Perciformes: Cichlidae) in Eleiyele Lake, South-western Nigeria. Revista Biologia. Tropica, 55: 969-977. [PubMed], [Web of Science ${ }^{\circledR}$ ]

[20] Zaranyika, M. F. 1997. Sources and Levels of Pollution Along Mukuvisi River. A Review. In N.A.G. Moyo (Ed.), Lake Chivero: A Polluted Lake. University of Zimbabwe Publications, Harare: 35-43.

[21] Fryer, G. TD.Iles. 1972. The Fishes of the Great Lakes of Africa. Their Biology and Evolution Oliver and Boyd, Edinburgh, Scotland.

[22] Mortuza, M.G. and Rahman, T. 2006. Length-weight relationship, condition factor and sex-ratio of freshwater fish, Rhinomugilcorsula (Hamilton) (Mugiliformes: Mugilidae) from Rajshahi Bangladesh. Journal of Bio-science, 14: 139141.

[23] Utete, B, and Dzikiti, B. 2013. Comparative Study of Maize Bran and Chicken Manure as Fish Feed Supplement: Effects on Growth Rate of Oreochromis Niloticus in Pond Culture Systems. International Journal of Aquaculture 3(6):23-29. 